\title{
Accounting of Reserves for Impairment of Inventory
}

\author{
Khamidullina G.I. \\ Kazan Federal University, Institute of Management, Economics and Finance, Kazan, 420008, Russia
}

Arzhantseva N.V.

Kazan Federal University, Institute of Language, 420008, Kazan, Russia

\section{Doi:10.5901/mjss.2014.v5n24p75}

\begin{abstract}
The article reveals the problems of the methods of reserves accounting for impairment of inventory. The authors offer and substantiate some recommendations how to improve reserves accounting allowing to create informational conditions to manage impaired inventory, and also basic documents and registry to keep record of the reserves for the inventory impairment.
\end{abstract}

Keywords: record keeping of the inventory, management of material and production stocks, impairment, impairment factors, reserves for impairment of inventories.

\section{Introduction}

The objective factors of inventory impairment are the reduction of the current market value, functional depreciation, full or partial loss of original characteristics due to non-observance of storage requirements, serviceable life expiry [1, 2]. A timely identification of the reasons for impairment has to be included into the general system of tasks to manage material and production stocks (MPS).

The disclosure of the fact of depreciation of commodity stocks and supplies (CSS) in the system of accounts testifies, on the one hand, about the capability of business management to effectively manage inventories, risks connected with tangible security, and, on the other hand, about the future possible losses of the enterprise connected with the depreciation of CSS $[3,4]$. In this respect the improvement of the methods of keeping record of inventory impairment is an absolutely topical issue.

\section{Method}

First of all, we are going to describe the peculiarities of inventory record in accordance with the requirements which influence keeping record of inventory impairment.

According to Russian accounting standards, the fact of impairment can be disclosed only by the means of accumulating reserves for impairment of inventory, and the inventory book value adjustment is not allowed for. IAS 2 "Inventories" allows for reduction of inventories as the result of their impairment [5].

In our opinion, due to impairment the issue of inventory cost adjustment should be treated depending on the revealed factor of impairment.

So, if the impairment is the result of full or partial loss of original qualities of inventory, it is necessary to carry out the cost adjustment by reducing the book value, since we are speaking about irreplaceable losses of economic benefits of an enterprise. In the case when functional depreciation is claimed to be the reason for tangible assets impairment, then it is necessary to disclose the reduction of the book value of inventories by means of direct write-off if there is no opportunity to use such kind of tangible assets for other purposes or their sale on the market.

If the impairment is revealed as the result of reduction of the current market value or functional depreciation, or of the future full loss of the original qualities, it needs to be adjusted by means of accumulation of reserves. Such adjustment of the tangible assets book value reflects objectively the projected value of future losses, admitting the possibility of their replenishment, for example, as the result of increase in their market value, sale of tangible assets before the expiry date.

In accordance with p.25 of the Accounting Standards 5/01 "Inventory recording" the reserves for inventory 
impairment are accumulated for the sum of the difference between the current market value and actual costs of inventories if the latter evaluation is higher than the current market value. At this, the level of current inventory value is defined on the basis of the information available to the enterprise before the date when financial statements are signed $[6,7]$.

This testifies that the change of price or actual costs of inventories from the balance sheet date to the date of signing the financial statements is claimed in accounting as the adjusting event after the balance sheet date. In this respect the sum of the reserve for impairment of inventory disclosed by the balance sheet date is subjected to adjustment in case of change of price or actual cost, the adjustment made for minus as well as for plus.

According to the Inventories Accounting Guidelines, the reserves for inventory impairment can be accumulated both for each unit of inventory and for separate kinds (groups) of similar and related commodity stocks and supplies. The reserve is formed only in the case when at the balance sheet date the actual costs of the finished commodity are higher than its market value [8].

In accordance with the above mentioned documents in accounting the allowance of the reserve is made only through increase in miscellaneous expenses, but its allowance recovery with the inventory issue or current market cost increase leads to the increase of miscellaneous incomes.

\section{Results}

The analysis of the Russian inventory recording showed that an overwhelming majority of enterprises don't observe the accounting regulations in inventory impairment disclosure and don't accumulate the reserves for inventory impairment, as the result of which the assets evaluation of such enterprises maybe unreal. The main reasons for not meeting the requirements are accounting labour intensity which increases with the necessity to accumulate, use, adjust the reserves for each inventory unit, and also the disparity in inventories accounting records and fiscal accounting.

However, the mentioned reasons cannot serve the basis to waiver the obligatory accounting requirements. At the same time, the tightness of general normative regulations in the sphere of inventories impairment recording also serve the deterrent for their implementation. In this respect, the order of recording of reserves for inventory impairment has to be an element of the accounting policy.

In our opinion, as a minimum it's necessary to provide the parameters given below for the inventory impairment recording in the accounting policy, and as a maximum, besides the general parameters provided by the accounting policy it is viable to work out a separate Regulations (for example, "Regulations for reserves for impairment of inventory") which would include both methodological and organizational issues for accumulation and usage of such reserves.

As the parameters of recording the reserves for inventory impairment subjected to disclosure in the enterprise accounting policy we treat the kinds of commodity stocks and supplies for which the reserves are accumulated; the periodicity of disclosure of the inventory impairment, accumulation and adjustment of the reserves; the determination of impairment materiality level to take the decision about the reserves accumulation; determination of the levels of analytical specification of the reserves recording; the order of admission of inventories impairment and the methods of calculation of the reserve supply capacity, its adjustment and usage; the basic documents, analytical records to register the reserves for inventory impairment.

So, it is viable to carry out the inventory impairment testing on the materials, finished commodities and goods. Regarding the unfinished goods we will follow Z.Tuyakova who considers the adjustment of the unfinished production cost through accumulation of reserves for impairment quite nonviable and hard to put into business practice.

The periodicity of the disclosure of the impairment factors should depend on the organization of the general system of inventories management. In case of due record and control for inventory state this can be done monthly. However, as we see, the optimal periodicity is the quarter as regards the reporting of data about the assets impairment both in interim financial reporting and management reports.

One of the principles of accumulation of reserves is the materiality of expenses andlor losses to clear which the reserve is accumulated $[10,11]$. In this case the materiality level may be the relative indicator of each inventory unit impairment by $5-10 \%$.

To organize analytical accounting of reserves for inventory impairment at the account 82 "Surplus Reserve" which we suggest, subaccount "Assessed reserves adjusting the assets assessment as the result of their impairment", tertiary account "Reserves for inventory impairment" it is necessary to provide the following levels of analytical specification: the kind of commodity stocks and supplies, factor of their impairment, the group they belong to or the reserve unit of inventory.

The institutionalization of the admitting impairment order in the enterprise accounting policy has to be precise. We 
recommend to implement this kind of order for each impairment factor.

Accumulation of the reserves, in our opinion, should be displayed out of profits. To do so we introduce the notion of an abstractive benefit of the accounting period and suggest taking it into account at the contra-liability account 85 "An abstractive benefit of the accounting period".

As for the reserve usage and adjustment we suggest an order of their disclosure different from the one provided by the current normative documents. In our opinion, instead of reserve recovery while the commodity stocks and supplies release or increase of the current market value it is viable to show its usage to cover the real losses from both the impaired inventory sale and the write-off of the obsolescent commodity stocks and supplies or the one which have completely lost their original qualities due to expiry.

To implement this suggestion it is necessary firstly to provide an additional analytical position at the accounts allowing to identify the impaired inventory by the reason of their impairment for inventory recording, and to include additional requisites allowing to indentify the inventory behavior into the basic documents on inventory record keeping. Secondly, to keep record of benefits and expense andlor write-off the impaired inventory it is necessary to provide an additional specification at the accounts 90 "Sales", "Other revenues and expenses" and 99 "Gains and losses".

Thus, it will be possible to reveal the write-offs and impaired inventory sales losses at the accounts, which have to be written off for the accumulated reserves by the end of every month or quarter.

The adjustment of the reserves for the commodity stocks and supplies impairment in our understanding is the change of their rests by the end of the accounting period with the account of their usage during the accounting period, and also new circumstances of the revealed fact of inventory impairment by the balance sheet date and events after the reporting date affecting the change of the current market value or inventory actual costs.

If according to the information about the revealed facts of inventory impairment at the end of the accounting period the accounted reserve will constitute a bigger sum than the one at the beginning of the accounting period lessened by the sum of its usage, then the reserve sum should be increased. In the reverse situation, when the accounted sum of the reserve is smaller than the sum of the reserve at the beginning of the accounting period lessened by the sum of its usage, then the sum of the reserve should be reduced.

To reveal the commodity stocks and supplies impairment it is necessary for the enterprise to organize a committee which would include the leading specialists of the marketing, materials and manufacturing departments as well as inventory managers.

The procedure of disclosure of the impairment by its factors should represent the gathering and analysis of information about the accounting and current market value of the inventory, about the statistics of inventory write-offs due to the expiry, projected value of the sales of the obsolete inventory.

We see the following advantages of the suggested order of the impairment recording as compared with the current one: firstly, the given order allows to reflect the real miscellaneous revenues and expenses; secondly, the absence of the necessity to recover the reserves with the inventory release and increase of the current market value simplifies the accounting procedures; thirdly, the recommended variant takes into account the impairment factors, which gives an opportunity to manage the risks of asset impairment more effectively; fourthly, the suggested order of accumulation, usage and adjustment of the reserve will let more clearly reflect the given information in the financial data reporting, which will make it more available for users' understanding.

\section{Conclusion}

Thus, the suggested recommendations on the improvement of reserves recording for the inventory impairment will contribute to the increase of the quality of the information about inventory impairment in the system of accounts.

\section{References}

Cushing B.E., LeClere M.J. Evidence on the Determinants of Inventory Accounting Policy Choice. The Accounting Review, 1992; 67(2): 355-366.

Mehar A. Simultaneous Determination of Inventories and Accounts Receivable. Managerial and Decision Economics, 2005; 26(4): 259269.

Wu J.-Z. Inventory write-down prediction for semiconductor manufacturing considering inventory age, accounting principle, and product structure with real settings. Computers \& Industrial Engineering, 2013; 65(1): 128-136.

Tsalavoutas I., André P., Evans L. The transition to IFRS and the value relevance of financial statements in Greece. The British Accounting Review, 2012; 44(4): 262-277.

International financial reporting standards. - M.: The Asker - ACCA, 2010. - 1064c. 
Order of the Ministry of Finance of Russian Federation 09.06.2001 № 44H «Ob utverzhdenii Polozheniya po buhgalterskomu uchetu «Uchet materialno-proizvodstvennyih zapasov» PBU 5/01».

Order of the Ministry of Finance of Russian Federation 06.05.1999 № 33н (edited 27.11.2006) «Ob utverzhdenii Polozheniya po buhgalterskomu uchetu «Rashodyi organizatsii» PBU 10/99».

Order of the Ministry of Finance of Russian Federation 28.12.2001 № 119H Ob utverzhdenii Metodicheskih ukazaniy po buhgalterskomu uchetu materialno-proizvodstvennyih zapasov»».

Juncos-Rabadán, O., Pereiro, A.X., Facal, D., Bóveda, J.,Eiroa, P. (2014). Prevalence and correlates of mild cognitive impairment in adults aged over 50 years with subjective cognitive complaints in primary care centers. Geriatrics and Gerontology International, 14 (3), pp. 667-673

latridis G.E. Accounting disclosures, accounting quality and conditional and unconditional conservatism. International Review of Financial Analysis, 2011; 20(2): 88-102.

Hughes S.B., Sander J.F., Snyder J.K. Critical accounting policy and estimate disclosures: Company response to the evolving SEC guidance. Research in Accounting Regulation, 2009; 21(1): 19-33. 